\title{
The Influence of Characteristics of Worker and Business on the Income of Informal Sector Workers in Yogyakarta
}

\author{
Jagad Hidayat Jati, Sri Rum Giyarsih, and Luthfi Muta'ali \\ Universitas Gadjah Mada, Yogyakarta \\ Corresponding Author: Sri Rum Giyarsih (email: srirum@ugm.ac.id)
}

\begin{abstract}
Yogyakarta has excellent human resources, but informal sector workers are threatened with low income. This article aims to examine how the influence of worker and business characteristics on informal sector workers' income in Yogyakarta. Characteristic of workers consist of education, work or business experience, status in the household, marital status, gender, and age. Then business characteristics consist of types of business fields, working days, hours of work, length of work, use of internet technology, and financial bookkeeping. The study was conducted quantitatively using secondary data sources obtained from the National Labor Force Survey (Sakernas) in August 2018. The data were analyzed using binary logistic regression. The findings show that both partially and simultaneously, each factor of the two characteristics has a significant influence on the income of informal sector workers in Yogyakarta.
\end{abstract}

Keywords: characteristic of workers; business characteristics; income; informal sector

\section{Introduction}

Yogyakarta has excellent human rsources capital. More than half of the Yogyakarta workforce has secondary and higher education levels of 52.4 percent (Statistics Indonesia, 2017a) in 2017. In the same year, the Human Development Index (HDI) of Yogyakarta reached 78.89, placing it on the second position after DKI Jakarta (Statistics Indonesia, 2018). These excellent human resources are a promising capital in the world of work because the production power will increase, thus the income also increases as well (Becker, 1975 and Purnastuti et al., 2015). However, the workforce in Yogyakarta is faced with a dichotomy in the world of work which is divided into the formal and informal sector. Those who work in the formal sector in an exact order and their income is quite high are seen to be the ones contributing to regional economic development (Becker, 2004). Meanwhile, the informal sector is seen as an unorganized economic sector and its economic contribution is doubtful since the workers have low and uncertain incomes (Pitoyo, 2007; Suharto, 2009).

Gerxhani \& van de Werhorst (2011) found that the higher the human capital, the reluctant they should be to enter the informal sector. Therefore, the informal sector is dominated by people with lower level of education who have low income (Werlin, 1974). With the superior human resources, there should be a lot of formal workers in Yogyakarta, but it was reported that many 
workers in Yogyakarta in 2017 workerd in the informal sector. Based on the news channel Sindo News, which presents the results of a Bank Indonesia survey, the number of informal sector workers in Yogyakarta reaches 54.91 percent (Sindo News, 2017). This makes the workers who work in the informal sector have the potential to have low income even though the quality of human resources in Yogyakarta is high. Reflecting on the national level as listed in Figure 1, the average income of the informal sector from 2013 to 2017 has always been lower than that of formal workers.

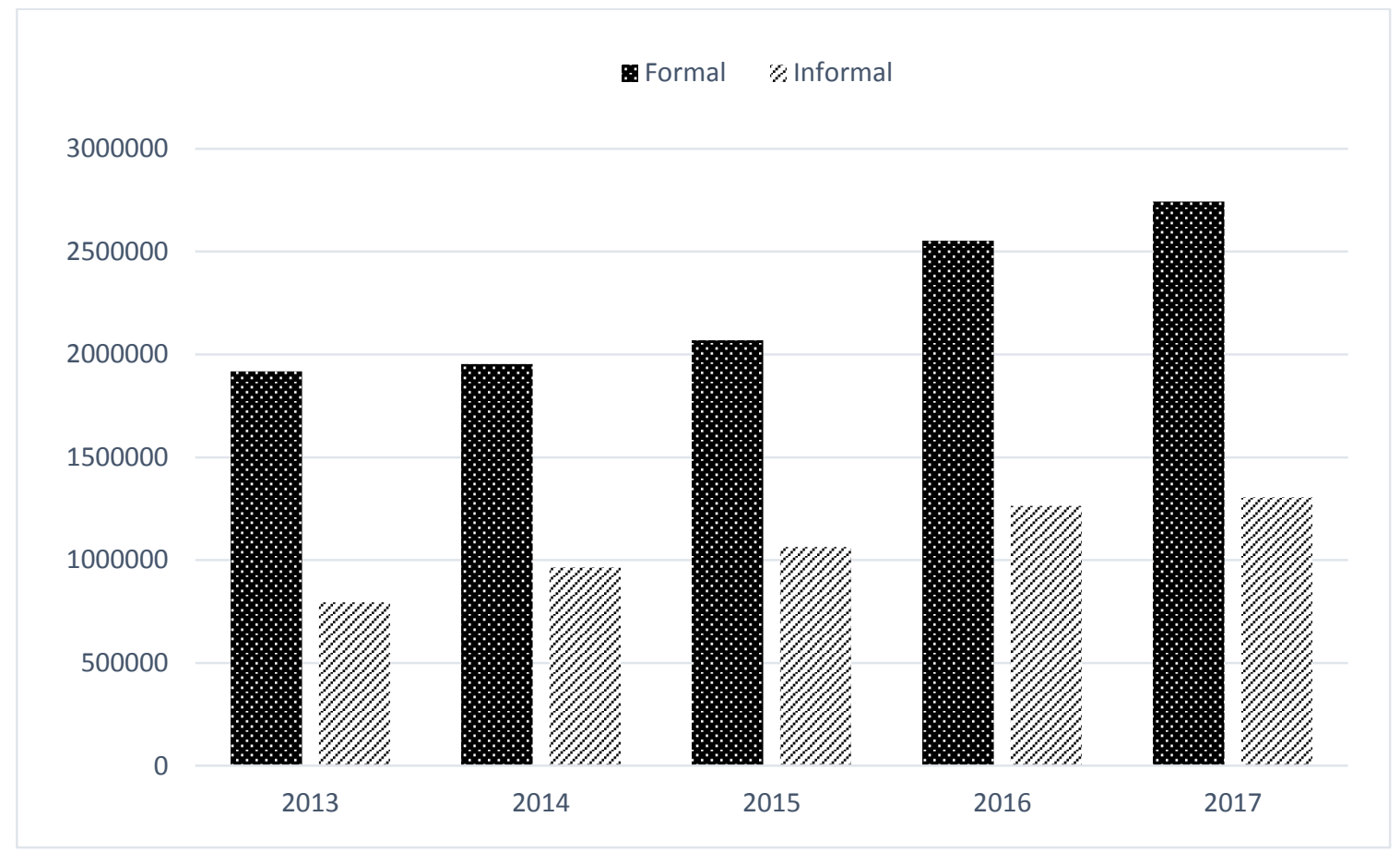

Source: Statistics Indonesia, 2014 and 2017b processed data

Figure 1. Average Income of Indonesian Workers per Month in 2013 - 2017

It is interesting to explore further that the workers in Yogyakarta have high human capital, but the relationship with their income in the informal sector has not found out yet. Other factors other than education also need to be linked to its influence. Work experience is also included as human resources capital (Pamungkas, 2013). Age, gender, and status in the household (Utomo, 2013) are factors that come from the socio-demographic characteristic of workers. The factors that come from the business characteristics of the informal sector can also have an influence. The business characteristics in the informal sector mentioned by Hidayat (1978, in Widodo, 2002) have also a relationship with income since the types of business they are involved in are very simple, i.e., those related to small goods or services. The informal sector business activities were also not well organized, the pattern of business activities was irregular, both in terms of location and working hours, the sub-sectors of work were also easy to change, and the technology was still very simple. The characteristics of business that is arguably less favorable than the formal sector makes the informal sector workers havelowincomes. Thecharacteristics 
of worker and the characteristics of business should be examined on how they affect the income of workers in Yogyakarta, so it how to increase the income, even though they are in the informal sector which is known to have lower income than the formal sector, can be seen. The income should be examined since it will contribute to the improvement of the people's welfare of the area (Priyono, 2002). Not to mention that income is also related to more macro matters, such as regional and national economic development. Although the contribution is not as big as the formal sector, it can at least improve income distribution (Nasution, 2015).

This article aims to examine the influence of characteristic of workers consisting of education level, work or business experience, status in household, marital status, gender, and age as well as business characteristics, i.e., business field, working days, working hours, length of work, the use of internet technology, and financial bookkeeping of the income of informal sector workers in Yogykarta. The specific theoretical significant of this study is to prove the influence of various factors on the income of informal sector workers in Yogyakarta. The practical significant of this study is to help the people of Indonesia, especially Yogyakarta, to find out what factors come from the characteristics of worker and business that can affect the income of informal sector workers so that it is hoped that people who will or are just entering the labor market can be encouraged to pay more attention these factors. Therefore, they can get higher income or even more than enough to meet their daily needs. The results of this study can also be used as a material for a consideration in the discussion of employment policy making in Yogyakarta regarding the empowerment of informal sector workers who have so far received little attention. The hypothesis used in this tsudy is that there is a partial or simultaneous influence between education level, work/ business experience, family membership status, marital status, gender, age, type of business field, working days, working hours, length of work, use of internet technology, and financial bookkeeping of the income of informal sector workers in Yogyakarta.

There are previous studies that examine thefactorsaffecting an income. However, there are still few who discuss about the informal sector, one of them is a study conducted by Paderi \& Mulyani (2018) which specifically takes a small scope of informal sector workers in Pasar Kembang, Yogyakarta. It was found that in this homogeneous environment, which was dominated by male informal workers with high school education, there was a significant relationship between working hours and income. Meanwhile, education level, total capital, length of work, and age tested were not related. Pratama's study (2013) on the analysis of income differentiation of the informal sector in Jalan Jawa, Jember reveals that in a small area where homogeneous types of business, the level of education does not have a significant influence, while other variables make a positive and significant contribution to the income of street vendors in Jalan Jawa. The most dominant variable is the diversity of the menu since it may become a characteristic for street vendors. Dewi et al. (2012), who examined canang traders in Badung, found that working hours, number of workers, business capital, and business location have a partial or significant influence on income. Other study on the informal sector comes from Lamba (2011) which generally and descriptively examined the conditions of the informal sector in Jayapura. The findings show that, in a broader scope such as the city level, there are heterogeneous conditions since the informal sector is very flexible in accepting workers with different backgrounds, so the variable of gender, age, ethnicity, level of education, and capital vary. By the heterogeneity of the informal sector in a broad scope, the factors that affect income can be seen as a whole without tilting to a certain domination. 
A study with a wider scope is that of taking a national scope like what Gesti (2016) conducted that took the national scope as a whole. Although the subject is not informal sector workers but industrial sector workers, the significant influence of education, work experience, gender, domicile, working hours, and industrial group on income was found. According to the study conducted by Cho \& Cho (2011), which targeted all workers in South Korea, the informality or formality of a sector affects the income of workers wherein the informal ones tend to get low income like the results of a study conducted by Rand \& Torm (2012) which examined differentiation of income between the formal and informal sectors in Vietnam. Moreover, Cho \& Cho (2011) revealed that there is a gender factor in which women tend to have lower income, then the education factor is higher, the income also increases, then there are also factors of marital status and type of business field. Rand \& Torm (2012) stated that income differentiation occurs due to differences in business scale, length of business, business owner's gender, education, number of workers, technology, and region. Based on the various previous studies, this study was prepared by taking the regional or provincial scope of Yogyakarta so that the sample may be heterogeneous without leaning towards certain groups. The hypothesized influential factor starts with the superior condition of human resources in Yogyakrta. By considering other factors and summarizing the previous research, it means that the selected factors come from the characteristics of worker and business. The characteristics of worker consist of education level, work or business experience, family membership status, marital status, gender, and age. The characteristics of the business consist of the type of business field, working days, working hours, length of work, use of internet technology, and financial bookkeeping.

\section{Methods}

Research design is a design that must be determined carefully and precisely so that the research results with good quality can be obtained (Pitoyo et al., 2017). The research design is based on quantitative research which means that the research will use an approach to test the theory by examining the relationship between variables. This study used secondary data analysis. The data source used for each variable came from the Statistics Indonesia (Statistics Indonesia) in the form of raw data for the Sakernas, one of the population data sources, especially those related to employment. Sakernas data collection was carried out twice a year, i.e., on February and August. The data used in this study was Sakernas data for the period of August 2018 which refers to the middle of the year which was expected to be able to represent the conditions of the year in balancing way with other considerations in the form of a larger sample size of 20,000 census blocks to the district/city level. The analysis unit used in this study was male and female household members aged 5 years and older who became the Sakernas respondents. Other conditions that had been met for the objective of this study were the region must be Yogyakarta, has a working status, and works in the informal sector. The research area is Yogyakarta consisting five regencies/cities (Bantul, Sleman, Kulon Progo, Gunungkidul, and City of Yogyakarta). Working is defined as an economic activity to earn income of at least 1 (one) hour continuously in a week before the enumeration day or usually carries out these activities but temporarily does not do it for some reason (Statistics Indonesia, 2017a). The definition of working in the informal sector uses the concept of Statistics Indonesia and is linked to the theory mentioned in the theoretical studies proposed by Werlin (1974) and (Sethuraman, 1985). Therefore, the definition of informal sector workers used in 
this study is those who employ themselves, either on their own, become free workers in agriculture, or become free workers in nonagricultural activities.

The data analysis used in this study is descriptive and inferential analysis. The use of descriptive analysis in this study facilitated the interpretation and explanation of the variables used by analyzing tables, graphs, or diagrams of processed data by presenting frequency, percentage distribution, or cross tables (Singarimbun, 1989). The inferential analysis was the independence test and binary logistic regression. The independence or association test was used to see the relationship between the independent variables and the dependent variables using chi square. Binary logistic regression was used to answer the second research problem, i.e., to find out the factors that affect the income of informal sector workers. The dependent variable consisted of income, while the independent variables consisted of education level, work/business experience, family membership status, marital status, gender, and age. Furthermore, the business characteristics consisted of types of business field, working days, working hours, length of work, use of internet technology, and financial bookkeeping. The logistic regression helped in analyzing categorical data or data with binary dependent variables with one or more independent variables on a continuous or categorical scale (Hosmer \& Lemeshow, 2000). The binary-scale dependent variables are variables that only produce two categories, i.e., events that are success and events that are fail (Widarjono, 2010). The dependent variable in this study was the income of informal sector workers in Yogyakarta, which in the inferential analysis was categorized into two categories, i.e., IDR $<1,500,000$ and IDR $\geq 1,500,000$ based on the Provincial Minimum Wage standard in 2018 which was then rounded up at IDR 1,500,000. (Tribun Jogja, 2018). The twelve independent variables were also divided into two categories based on high-low or yesno. This logistic regression model is a nonlinear model. The transformations for linear logistic regression use logit transformations as follows:

$$
g(x)=\ln \left[\frac{\pi(x)}{1-\pi(x)}\right]=\beta_{0}+\beta_{1} x_{1}+\cdots+\beta_{p} x_{p}
$$

The model used to examine the factors influencing the income of informal sector workers in this study is presented as follows.

$$
\begin{gathered}
P D P=\ln \frac{\pi}{1-\pi}=\beta_{0}+\beta 1_{P N D D}+\beta 2_{P E N G}+\beta 3_{R U T A}+\beta 4_{K A W I N}+\beta 5_{J K}+\beta 6_{U M U R}+\beta 7_{L A P U} \\
+\beta 8_{H A R I}+\beta 9_{J A M}+\beta 10_{L A M A}+\beta 11_{I N T E}+\beta 12_{B U K U}
\end{gathered}
$$

Annotation:

PDP

$\ln \frac{\pi}{1-\pi}$

PNDD

PENG

RUTA

KAWIN

JK
$=$ Income of Informal Sector Workers

= Odd Ratio

$=$ Education

$=$ Working / Business Experiences

$=$ Family membership status

$=$ Marital Status

$=$ Gender

\section{UMUR \\ $=$ Age}

LAPU = Types of Business Field

HARI = Working Days

JAM = Working Hours

LAMA = Working Period

INTE = Use of Technology (Internet)

BUKU = Financial bookkeeping

BO $\quad=$ Intercept

$\beta 1,2,3,4,5,6,7,8,9,10,11,12=$ Regression

Coefficient 


\section{Discussion}

Based on the raw data of the Sakernas Statistics Indonesia 2018 that had been processed, there were 23.4 percent or 503,409 people of the total population who worked independently and had income in the informal sector in 2018. Meanwhile, 31.6 percent of informal workers were assisted by irregular labor/family workers/unpaid workers and family workers/unpaid workers consisted of 679,194 people. There was 45 percent of formal workers or 966,555 people. Based on the above data, the total informal sector in Yogyakarta in 2018 was 55 percent, higher than the formal sector, i.e., 45 percent only. However, what is meant by informal sector workers in this tsudy only referred to 23.4 percent workers who worked alone with an income in the form of money or goods. The informal sector workers in Yogyakarta, who were included in the analysis unit according to their domicile, were spread across fur districts and one city. It can be seen in Table 1 below that Sleman has the highest number of informal sector workers with 31.1 percent. The informal sector workers domiciled in Yogyakarta were the lowest ones compared to those domiciled in four other regions, i.e., 8.6 percent only.

\section{Table 1. Percentage of Domicile Distribution of Informal Sector Workers in Yogyakarta in 2018}

\begin{tabular}{lrr}
\hline City/District & Number & $\mathbf{( \% )}$ \\
\hline Bantul & 133.790 & 26.6 \\
Gunung Kidul & 114.411 & 22.7 \\
Kulon Progo & 55.110 & 10.9 \\
Sleman & 156.736 & 31.1 \\
City of Yogyakarta & 43.362 & 8.6 \\
TOTAL & 503.409 & 100 \\
\hline
\end{tabular}

Source: Raw data from SAKERNAS Statistics Indonesia 2018, processed

Regarding the income, there was a fairly varied distribution of income, starting from under IDR 750,000 to some which is more than double the Regional Minimum Wages standard or more than IDR $3,000,000$. Table 2 presents the income of informal sector workers who worked alone with the income in the form of money and goods in Yogyakarta. Based on the table, most of the informal sector workers earned less than IDR 750,000 , amounting to 33.5 percent. It indicates that there were informal workers in Yogykarta who were not even able to achieve an income of half the value of the Regional Minimum Wages standard. Even so, there were 9.7 percent of the informal workers who earned more than double the Regional Minimum Wages standard. Based on the achievement of the Regional Minimum Wages to meet the standard of basic daily needs, 60.1 percent of the informal sector workers had not achieved it. In 2018, there were only 39.8 percent of informal workers in Yogyakarta whose income reached the Regional Minimum Wages standard. 
The Influence of Characteristics of Worker and Business on the Income of Informal Sector Workers in Yogyakarta

Table 2. Income Level of Informal Sector Workers in Yogyakarta 2018 (IDR)

\begin{tabular}{lrr}
\hline Income & Number & $\mathbf{( \% )}$ \\
\hline$<750.000$ & 168,809 & 33.5 \\
$750,000-1,499,999$ & 133,995 & 26.6 \\
$1,500,000-2,249,999$ & 126,763 & 25.2 \\
$2,250,000-2,999,999$ & 24,832 & 4.9 \\
$\geq 3,000,000$ & 49,010 & 9.7 \\
TOTAL & 503,409 & 100 \\
\hline
\end{tabular}

Source: Raw data from SAKERNAS Statistics Indonesia 2018, processed

Based on the characteristics of the workers, most of the informal sector workers in Yogyakarta came from high SMA/ SMK/other education with the same level at 31.4 percent. The interesting thing is that there were informal workers with the highest education level, i.e., postgraduate, amounting to 0.4 percent. If it is separated into two categories between those with education below SMA/SMK/ other education with the same level and those with higher education level, then those who had the lower education level dominated the number, i.e., 60.2 percent, while those who had studied for 12 years or more were 39.8 percent. Regarding the work/business experience, 71.4 percent of the informal sector workers in Yogyakarta had previously had other jobs, either in formal sector or moving from other informal work/business. There were only 26.6 percent of workers working for the first time and directly entered the informal sector. Almost three quarters of the informal sector workers based on their family membership status was the head and the spouse of the household. There were 74.7 percent of the informal sector workers were the head of the household, either a husband or a wife who was usually responsible for supporting the family as well. The rest were other household members, whether had a family relation or not. The informal sector workers were dominated by those whose marital status was married or had been married but had got divorced, i.e., 86.4 percent. There were 59.3 percent of male informal workers and 40.7 percent were female. The last characteristic, i.e., age, did not indicate the presence of informal sector workers aged under 15 years. The productive age group of 15-64 years was 88.8 percent of all informal sector workers in total. The most productive age group was informal sector workers aged 45 - 54 years, i.e., 25.1 percent, followed by those aged $35-44$ years, i.e., 22.2 percent. There were 11.2 percent elderly informal workers aged 65 years.

Based on the characteristics of business, the first characteristic is the type of business field. In 2018, the informal sector in Yogyakarta had the dominant types of business in the form of trade, restaurants, and accommodation services at 26.8 percent. It was then followed by the type of business, i.e., agriculture by 20.2 percent. If it is classified into two categories, i.e., manufacture-agriculture and services, the total type of business that is included in the agriculture-manufacturesector is 36.5 percent, while the type of service is 63.5 percent. The working day of informal sector businesses in Yogyakarta was dominated by those who worked 25-30 days a month, i.e., 70.8 percent. It means that there were workers who fully worked in a month without any days off and some only took 1-3 days off in a month. There are informal workers who work routine formal employee days, namely 
5-6 days per week or 20-24 days per month as much as 16.4 percent. There were those whose working days were less than half a month, i.e., 7.4 percent. Based on the working hours, the standard definition of working hours according to Statistics Indonesia is more than 35 hours during a week means working full time, while the working hours under 35 hours per week means underemployment. There were 34.6 percent of informal sector workers in Yogyakarta who worked with underemployment status. The remaining, i.e., 65.4 percent of the workers, were fulltime workers. The next factor from the characteristics of business is a long history of work. There were 17.6 percent of the informal workers who had worked for less than one year. It means that they have just entered the world of work or started a business. Most informal sector workers in Yogyakarta had worked for 1-5 years, i.e., 29.1 percent. It was then followed by 20.4 percent of the workers who had workerd for up to 20 years. Overall, 24.8 percent of the informal sector workers had used internet technology. Those who had used financial bookkeeping in their business were 19.3 percent.

The Relationship between Characteristics and Income

Before looking at the influence, the characteristics of the workers and the characteristics of the business, which each consist of six variables, this study found out the relationship with income first. Table 3 shows that the six variables of characteristic of workers have a significant relationship with the income of informal sector workers in Yogyakarta in 2018. This relationship was obtained from the chi square test, all of which showed a significance value of 0.000 or a value of $<0.05$. Therefore there was a significant relationship between the six variables and income. In addition to the chi square, there was a correlation coefficient showing the direction of the positive or negative relationship as well as a risk estimate showing the probability of how big the relationship is. 
Table 3. The Relationship between Characteristic of Workers and Income of Informal Sector Workers in Yogyakarta in 2018

\begin{tabular}{|c|c|c|c|c|c|c|c|c|c|}
\hline \multirow[t]{2}{*}{ Variable } & \multirow[t]{2}{*}{ Category } & \multicolumn{4}{|c|}{ Income } & \multirow[t]{2}{*}{$\mathrm{n}$} & \multirow[t]{2}{*}{$\begin{array}{c}\text { Pearson } \\
\text { Chi- } \\
\text { Square } \\
\text { Sig. } \\
\end{array}$} & \multirow[t]{2}{*}{$\begin{array}{l}\text { Correlation } \\
\text { coefficient }\end{array}$} & \multirow[t]{2}{*}{$\begin{array}{c}\text { Risk } \\
\text { Estimation }\end{array}$} \\
\hline & & $<1,500,000$ & $(\%)$ & $\geq 1,500,000$ & (\%) & & & & \\
\hline Education & 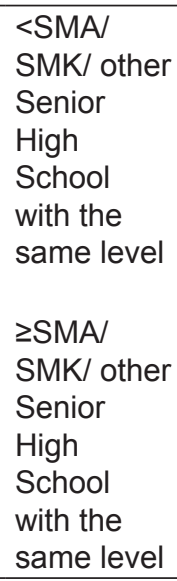 & 206614 & 68.2 & 96450 & 31.8 & 303064 & 0.000 & 0.202 & 2.320 \\
\hline $\begin{array}{l}\text { Work/ } \\
\text { Business } \\
\text { Experience }\end{array}$ & $\begin{array}{l}\text { No } \\
\text { Yes }\end{array}$ & $\begin{array}{r}88809 \\
213995\end{array}$ & 61.6 & $\begin{array}{r}55415 \\
145190\end{array}$ & $\begin{array}{l}38.4 \\
40.4\end{array}$ & $\begin{array}{l}144224 \\
359185\end{array}$ & 0.000 & 0.018 & 0.920 \\
\hline $\begin{array}{l}\text { Family } \\
\text { membership } \\
\text { status }\end{array}$ & $\begin{array}{l}\text { Other } \\
\text { family } \\
\text { and other } \\
\text { relation } \\
\text { Head of } \\
\text { Family } \\
\text { and His } \\
\text { Spouse }\end{array}$ & 69069 & 54.2 & 58251 & 45.8 & $\begin{array}{r}127320 \\
376089\end{array}$ & 0.000 & -0.070 & 0.722 \\
\hline $\begin{array}{l}\text { Marital } \\
\text { Status }\end{array}$ & $\begin{array}{l}\text { Not } \\
\text { Married } \\
\text { Yet } \\
\text { Married, } \\
\text { Divorced } \\
\text { Lived/ } \\
\text { Passed } \\
\text { Away }\end{array}$ & 39528 & 57.9 & 28703 & 42.1 & 68231 & 0.000 & -0.018 & 0.899 \\
\hline Gender & $\begin{array}{l}\text { Female } \\
\text { Male }\end{array}$ & $\begin{array}{l}163344 \\
139460 \\
\end{array}$ & $\begin{array}{l}79.7 \\
46.7 \\
\end{array}$ & $\begin{array}{r}41582 \\
159023 \\
\end{array}$ & $\begin{array}{l}20.3 \\
53.3 \\
\end{array}$ & $\begin{array}{l}204926 \\
298483 \\
\end{array}$ & 0.000 & 0.331 & 0.223 \\
\hline Age & $\begin{array}{l}<15 \text { and } \\
\geq 65 \text { years } \\
15-64 \\
\text { years }\end{array}$ & 48576 & 86.3 & 7713 & $\begin{array}{l}13.7 \\
43.1\end{array}$ & $\begin{array}{r}56289 \\
447120\end{array}$ & 0.000 & 0.189 & 4.778 \\
\hline
\end{tabular}


The results of the analysis showed that there were two variables had a positive direction of relationship, i.e., family membership status and marital status which showed a negative correlation coefficient. It means that the second category of each variable actually shows a reduction in income. It can be seen from the cross tabulation between the family membership status and income, the head of the household and their spouse who had a high income was only 37.9 percent, while other families status who had high income were 45.8 percent. The risk estimate of 0.722 showed that those with the status of the head of the household and their spouse had a 0.722 times greater chance of getting low income than those other families status or other status. Based on the cross tabulation between marital status and income, 45.8 percent of unmarried the informal sector workers had high incomes but only 37.9 percent of them whp had/had ever got married had high incomes. There was a risk estimate value of 0.899 , so those who had/had ever got married had a 0.899 times greater chance of getting low income than those who had never got married. The other four variables had a positive relationship direction so that each of the second category had the opportunity to get higher income, i.e., those who were highly educated, had business experience, were male, and were of productive age (15-64 years).

Different from the characteristics of business, each variable also showed a significant relationship where the result of the sixth chi square was 0.000 or below the value of 0.5 . In contrast to the characteristics of worker, each variable in business characteristics had a positive direction of the relationship so that the second category of each variable had the opportunity to get a higher income than the first category. It can be seen in Table 4 in which 50.4 percent of the types of non-agriculture/manufacture had high income compared to informal sector workers who were in the agriculture/ manufacture, i.e., only 19.4 percent of them who had high income, the remaining earned less than IDR 1.5 million per month. Based on the risk estimate, the type of non-agriculture/ manufacture had a 4.236 times greater chance of getting high income than those working in agriculture and manufacturing.

Table 4. The Relationship between Characteristic of Business and Income of Informal Sector Workers in Yogyakarta in 2018

\begin{tabular}{|c|c|c|c|c|c|c|c|c|c|}
\hline \multirow{2}{*}{ Variable } & \multirow{2}{*}{ Category } & \multicolumn{4}{|c|}{ Income } & \multirow{2}{*}{$\mathbf{n}$} & \multirow{2}{*}{$\begin{array}{c}\text { Pearson } \\
\text { Chi-Square } \\
\text { Sig. }\end{array}$} & \multirow{2}{*}{$\begin{array}{l}\text { Correlation } \\
\text { coefficient }\end{array}$} & \multirow{2}{*}{$\begin{array}{c}\text { Risk } \\
\text { Estimation }\end{array}$} \\
\hline & & $<1.500 .000$ & $(\%)$ & $\geq 1.500 .000$ & $(\%)$ & & & & \\
\hline \multirow{2}{*}{$\begin{array}{l}\text { Types of } \\
\text { Business } \\
\text { Field }\end{array}$} & $\begin{array}{l}\text { Agriculture \& } \\
\text { Manufacture }\end{array}$ & 138142 & 80.6 & 33159 & 19.4 & 171301 & 0.000 & 0.301 & 4.236 \\
\hline & $\begin{array}{l}\text { Non- } \\
\text { agriculture/ } \\
\text { Manufacture }\end{array}$ & 164662 & 49.6 & 167446 & 50.4 & 332108 & & & \\
\hline \multirow{2}{*}{$\begin{array}{l}\text { Working } \\
\text { Days }\end{array}$} & $<20$ days & 50776 & 84.1 & 9603 & 15.9 & 60379 & 0.000 & 0.181 & 4.007 \\
\hline & $\geq 20$ days & 252028 & 56.9 & 191002 & 43.1 & 443030 & & & \\
\hline \multirow{2}{*}{$\begin{array}{l}\text { Working } \\
\text { Hours }\end{array}$} & $<35$ hours & 142500 & 81.9 & 31571 & 18.1 & 174071 & 0.000 & 0.322 & 4.759 \\
\hline & $\geq 35$ hours & 160304 & 48.7 & 169034 & 51.3 & 329338 & & & \\
\hline \multirow{2}{*}{$\begin{array}{l}\text { Working } \\
\text { Period }\end{array}$} & $<1$ year & 58212 & 65.6 & 30584 & 34.4 & 88796 & 0.000 & 0.051 & 1.323 \\
\hline & $\geq 1$ year & 244592 & 59.0 & 170021 & 41.0 & 414613 & & & \\
\hline \multirow{2}{*}{$\begin{array}{l}\text { Used of } \\
\text { Technology } \\
\text { (Internet) }\end{array}$} & No & 252801 & 66.7 & 125977 & 33.3 & 378778 & 0.000 & 0.235 & 2.995 \\
\hline & Yes & 50003 & 40.1 & 74628 & 59.9 & 124631 & & & \\
\hline \multirow{2}{*}{$\begin{array}{l}\text { Financial } \\
\text { bookkeeping }\end{array}$} & Don't know & 255303 & 62.8 & 151130 & 37.2 & 406433 & 0.000 & 0.111 & 1.759 \\
\hline & Yes & 47501 & 49.0 & 49475 & 51.0 & 96976 & & & \\
\hline
\end{tabular}

Source: Raw data from SAKERNAS Statistics Indonesia 2018, processed 
Other variables besides the type of business field had a risk estimate above 1 (one), the highest variable was working hours, i.e., 4.759 , so the opportunity for working in full time was greater to get the high income than the informal sector workers who less ( $<35$ hours a week). The opportunities can be seen from the cross tabulation, i.e., 51.3 percent of those who worked full time got high income while those did not were 18.1 percent only. There were 81.9 percent of non-full time workers earning less than IDR 1.5 million. The other four variables showed a similar thing, i.e., those who worked $\geq 20$ days during a month had a greater chance of getting high income than those who worked under 20 days. The same thing was that the informal sector workers who had worked for more than 1 (one) year, used technology (internet), and had financial bookkeeping had respectively a higher chance of working for less than 1 (one) year, did not use the internet, and dod not have financial bookkeeping.

The Influence of Characteristics on Income

Based on the influence of the twelve variables of worker and business characteristics on income, binary logistic regression that showed similar results with the relationship test. The authors found that each variable had a significant influence on the income of informal sector workers in Yogyakarta in 2018 (Jati, 2020) partially or separately. This can be seen in Table 5 that the significance value of each variable is 0.000 or below 0.5 , so it has a significant influence.

\section{Table 6. Partial Logistic Regression Determinants of the Income of Informal Sector Workers in Yogyakarta in 2018}

\begin{tabular}{lrr}
\hline \multicolumn{1}{c}{ Variable } & B & Sig. \\
\hline Education & 0.633 & 0.000 \\
Work/Business Experience & 0.093 & 0.000 \\
Family Membership Status & -0.063 & 0.000 \\
Marital Status & -0.659 & 0.000 \\
Gender & 1.599 & 0.000 \\
Age & 0.552 & 0.000 \\
Types of Business Field & 1.001 & 0.000 \\
Working Days & 0.935 & 0.000 \\
Working Hours & 1.104 & 0.000 \\
Working Period & 0.773 & 0.000 \\
Use of Technology (Internet) & 0.815 & 0.000 \\
Financial Bookkeeping & 0.377 & 0.000 \\
\hline
\end{tabular}

Source: Raw data from SAKERNAS Statistics Indonesia 2018, processed

When all the variables were tested together for their influence on the income of informal sector workers, the regression value showed that all variables had simultaneously an influence. It is found that the Negelkerke $\mathrm{R}$-Square value was 0.388 , meaning that all variables have a significant influence on income of 38.8 percent. 


\section{Table 7. Simultaneous Logistic Regression Determinants of Informal Sector Worker Income in Yogyakarta in 2018}

\begin{tabular}{lccc}
\hline Step & $-\mathbf{2}$ Log likelihood & Cox \& Snell R Square & Nagelkerke R Square \\
\hline 1 & $506633.832^{a}$ & 0.287 & 0.388 \\
\hline Source: & Raw data from SAKERNAS Statistics Indonesia 2018, processed
\end{tabular}

The influence of variables by the characteristics of worker and the characteristics of business partially and simultaneously on income is in accordance with various theories and results of previous research. Although there are 2 (two) variables of the characteristics of worker that have the opposite influence, i.e., family membership status and marital status which showed a negative beta $(B)$ value in the partial regression. If this is seen one by one starting from education, the influence shows a value of 0.633 , so there is a positive influence of the level of education on the income of informal sector workers. The higher the education, the higher the income. This influence is in accordance with the theory proposed by Lutz \& Samir (2011) that a high educational background will also increase economic opportunities in a better direction, one of which is earning income. The variable of work/business experience also showed a positive value of 0.093 . Therefore, there is a positive influence of work/business experience on the income of informal sector workers. The more experienced the workers are, the higher their income will be, just like the theory proposed by Manulang (1984) which states that previous work experience is a knowledge formation process that contributes to increased skills so that higher income can be achieved.

The third variable, i.e., the family membership status, showed a negative value of -0.063 , so there is an influence of family membership status on the income of informal sector workers even though the influence is negative. The higher the family membership status in the household (the head and his spouse), the lower their income. The findings of Salehuddin \& Imam (1998) are contrary to the results of this study in which the findings indicate that having the family membership status (the head or his spouse) or already married among retail traders of Blitar Municipality will increase their income. The next variable which is influential and contrary to this theory is the variable of marital status where the regression result showed a negative value, i.e., -0.659 . Therefore, the marital status in Yogyakarta had a negative influence on the income of informal sector workers (Jati, 2020). When a worker got married or divorced, the income would actually decrease. The gender variable showed a regression value of 1.599 , so it there was a positive influence of gender on the income of informal sector workers. The higher income was obtained by the male workers. This influence is in accordance with the theory proposed by Cho \& Cho (2011) which found that being a woman in the world of work in South Korea tends to earn lower income than men. The sixth order that came from the characteristics of worker is the variable age. This variable showed a positive regression value of 0.552 . There was a positive influence of age on the income of informal sector workers, meaning that the more productive the workers are, the higher their income. The theory proposed by Cho \& Cho (2011) is also consistent with these findings. Their study indicated that apart from gender, there is age that influences income.

Based on the variables originating from the characteristics of the business, the six variables of this category had a positive influence. The first variable is the type of 
business field which showed the beta value (B) of 1.001. It means that when they were in a non-agriculture/manufacture field of work, the income would be higher. The findings of Tiwari's study (2006) regarding informal workers in India are similar to this study, i.e., those who work in services or non-agriculture/manufacture will get higher incomes. In this study, working days became a variable that had a positive value of 0.935 , so the more days spent for working, the higher the income. This is consistent with research findings from Pratama (2013) which revealed that the income of informal sector workers in Jalan Jawa, Jember will increase if the time spent for working increases. It is the same as the working hours variable which in this study showed the similar findings, i.e., a positive value of 1.104. The more hours used by the informal sector workers in Yogyakarta to work, the higher their income would be. Gesti (2016) previously conducted a related research in which industrial sector workers in Indonesia in 2014 who worked full hours (35 hours or more) would have a higher income level than workers who worked less working hours. The next variable is working duration which showed the positive influence of the regression value of 0.773 . It can be said that the longer people work in an informal business, the higher their income. The theory that is in line with this study is Medoff's theory (1980 in Pratama, 2013) which said that the longer a person works in one main job, the more income will be increased because their productivity increases as experience accumulates into expertise. The variable of the use of technology (internet) showed a positive influence, such as the variable from other characteristic of business, i.e., a value of 0.815 . It means that the more a business uses technology in the form of the internet, the higher the income will be. The variable of financial bookkeeping showed a positive regression value of 0.377 , thus the more a business uses a tool in the form of financial bookkeeping, the higher the income will be. The findings on these two variables are consistent with the findings of a study conducted by Dewi (2014) and Widodo (2002) which revealed that technology or assistance in a business will increase productivity which then affects the increase in income.

\section{Conclusion}

The income achievements of informal sector workers in Yogyakarta in 2018 were still below the Regional Minimum Wages standard and some were already high above it. There were 39.8 percent of the informal sector workers who had sufficient income according to the Regional Minimum Wages standard. Based on the findings of this study, those with high incomes came from secondary education level or above, had work or business experience, were not the head of the household, had not married yet, were male, and had productive age compared to those who were not. Based on the characteristics of the business, they worked at non-agriculture or manufacture, the work days of 20 days or more in a month, full working hours of more than 35 hours a week, working hours of more than a year, and use of the internet and financial bookkeeping. The results of this study confirmed the theory of the influence of characteristic of workers and the theory of the influence of business characteristics on the income of informal sector workers. It idnicated that the variables of education level, work or business experience, family membership status, marital status, gender, age, type of business field, working days, working hours, length of work, use of internet technology, and financial bookkeeping have an influence on the income of informal sector workers in Yogyakarta in 2018. Each variable also has its own influence partially.

Some recommendations intended to the Provincial Government of Yogyakarta or related agencies responsible for informal sector workers should pay more attention 
to the welfare of workers, which so far have not been given attention. Even though the informal sector workers seem unregulated and running independently, it will be much better if the government or related agencies help their work process through supportive programs, e.g., the arrangement of areas for informal sector workers to make them more organized, crowded, and attractive. Besides, providing them loan remission or stimulants will make their businesses develop or at least achieve an income equivalent to the Regional Minimum Wages standard, given that there are most informal workers whose income does not reach the Regional Minimum Wages standard. As a preventive action for the future to reduce the number of people with low income, the government and related agencies should boost their education programs, create skills training, provide internet access, and other ways related to variables that have a positive influence as found in this study.

\section{Acknowledgment}

This article is part of a thesis written by the first author under the guidance of the second author and the third author. The authors expressed their gratitude to the Graduate School of Gadjah Mada University which has funded this study and the Statistics Indonesia in Yogyakarta which has provided data for processing.

\section{References}

Becker, Gary S. 1975. Human Capital, A Theoretical and Empirical Analysis with Special Reference to Education, 292nd Edition. Accessed from http://www.nber. org/chapters/c373.

Becker, Kristina Flodman. 2004. Fact finding study: The Informal Economy. Stockholm: SIDA.

Cho, Joonmo \& Donghun Cho. 2011. "Gender difference of the informal sector wage gap: a longitudinal analysis for the Korean labor market". Journal of the Asia Pacific Economy, 16(4), 612-629. Routledge: Francis \& Taylor Group.

Dewi, Putu Martini. 2014. "Pengaruh Modal, Tingkat Pendidikan, dan Teknologi Terhadap Pendapatan Usaha Mikro Kecil dan Menengah (UMKM) di Kawasan Imam Bonjol Denpasar Barat". E-Jurnal EP Unud, 3 (12), 576-585. Faculty of Economics and Business, Udayana University.

Gerxhani, Klarita dan Herman G. van de Werfhorst. 2011."The Influence of Education on Informal Sector Participation in a Post-Communist Country". European Sociological Review, Vol. 0, No. 0. Oxford Journals Online.

Gesti, Heni Novita. 2016. "Analisis Determinan Pendapatan Tenaga Kerja Sektor Industri di Indonesia Tahun 2014". Jurnal Pendidikan dan Ekonomi, Volume 5, Nomor 5. State University of Yogyakarta. Hosmer, D. W., \& Lemeshow, S. 2000. Applied Logistic Regression: Second Edition. New York: John Wiley \& Sons, Inc.

Jati, J.H. 2020. Determinan Pendapatan Pekerja Sektor Informal di Daerah Istimewa Yogyakarta (Analisis Data SAKERNAS 2018). Thesis. Universitas Gadjah Mada. Unpublished Thesis.

Lamba, Arung. 2011."Kondisi Sektor Informal Perkotaan dalam Perekonomian Jayapura-Papua." Jurnal Ekonomi Bisnis, TH 16.

Lutz, Wolfgang dan Samir KC. 2011. "Global Human Capital: Integrating People and Population". SCIENCE, Vol. 333, No. 6042, pp. 587-592. American Association for the Advancement of Science.

Manulang. 1984. Manajemen Personalia. Ghalia Indonesia: Jakarta.

Nasution, Ade Parlaungan. 2015. "Pemberdayaan Sektor Ekonomi Informal: Suatu Tinjauan Empiris". Jurnal Dimensi, Vol. 4, No. 2. 
Paderi, Galang Topan \& R.R. Wiwik Puji Mulyani. 2018. "Karakteristik dan Analisis Pendapatan Pekerja Sektor Informal di SekitarPasar Kembang, Sosromenduran, Gedongtengen, Yogyakarta". Jurnal Bumi Indonesia Vol 7 No 2. Faculty of Geography, Universitas Gadjah Mada.

Pamungkas, Nur Cahyo Dian. 2013. Tingkat Pengembalian Investasi Pendidikan (Rate Of Return To Education) Tenaga Kerja di Provinsi Daerah Istimewa Yogyakarta Tahun 2011. State University of Yogyakarta.

Pitoyo, Agus Joko, Kiswanto, E., Kutanegara, P. M., \& Sumini. 2017. Manajemen Survei Kontemporer. Yogyakarta: Indie Book Center CPPS UGM.

Pitoyo, Agus Joko. 2007. "Dinamika Sektor Informal di Indonesia: Prospek, Perkembangan, dan Kedudukannya dalam Sistem Ekonomi Makro". Populasi, 18(2). ISSN: 0853-6202.

Pratama, Endi Rusmanhadi. 2013. Analisis Differensiasi Pendapatan Sektor Informal di Jalan Jawa Kabupaten Jember. Universitas Jember.

Priyono, Edy. 2002. "Mengapa Angka Pengangguran Rendah di Masa Krisis ? : Menguak Peranan Sektor Informal Sebagai Buffer Perekonomian". Jurnal Ekonomi dan Kewirausahaan Vol.1 No.2 July 2002.

Purnastuti, Losina; Daru Wahyuni; \& Mustofa. 2015. "Analisis Tingkat Pengembalian Investasi Pendidikan di Daerah Istimewa Yogyakarta". National Seminar Proceedings of State University of Yogyakarta on 9 May 2015. Yogyakarta: State University of Yogyakarta.

Rand, John \& Nina Torm. 2012. "The Informal Sector Wage Gap Among Vietnamese Micro-firms". Journal of the Asia Pacific Economy Vol. 17, No. 4, November 2012. Routledge Taylor \& Francis Group.

Salehuddin, Riyadi dan Subekti Imam. 1998. Analisa Beberapa Faktor yang Memengaruhi Kinerja usaha Pedagang
Eceran di Kotamadya Blitar. Research Report of Malang: Research Institute of Brawijaya University.

Sethuraman, S.V. 1985. "The informal sector in Indonesia: Policies and prospects". International Labour Review, Vol. 124, No. 6, November-December. EBSCO Publishing.

Sindo News. 2017. "Ekonomi Melambat, Pekerja Informal di DIY Malah Naik". https://ekbis.sindonews.com/ $\mathrm{read} / 1173046 / 34 /$ ekonomi-melambatpekerja-informal-di-diy-malahnaik-1485054529, accessed December 28, 2019.

Singarimbun, M., \& Effendi, S.1989. Metode Penelitian Survei. Jakarta: LP3ES.

Statistics Indonesia. 2014. Keadaan Pekerja di Indonesia Agustus 2014. DKI Jakarta: Statistics Indonesia.

Statistics Indonesia. 2017a. Statistik Ketenagakerjaan Daerah Istimewa Yogyakarta 2016-2017. Daerah Istimewa Yogyakarta: Statistics Indonesia in Yogyakarta.

Statistics Indonesia. 2017b. Keadaan Pekerja di Indonesia Agustus 2017. DKI Jakarta: Statistics Indonesia.

Statistics Indonesia. 2018. "Indeks Pembangunan Manusia menurut Provinsi, 2010-2018 (Metode Baru)". https://www.Statistics Indonesia.go.id/ dynamictable/2016/06/16/1211/indekspembangunan-manusia-menurutprovinsi-2010-2018-metode-baru-.html, accessed on March 29, 2019.

Suharto, E. 2009. Kemiskinan dan Perlindungan Sosial di Indonesia: Menggagas Model Jaminan Sosial Universal Bidang Kesehatan. Bandung: Alfabeta Publisher.

Tiwari, R. S. 2006. "Income, Consumption and Poverty Levels in Urban Informal Sector: Findings of a Field Study". Indian Journal of Industrial Relations, Vol. 41, No. 4. Shri Ram Centre for Industrial Relations and Human Resources. 
Tribun Jogja. 2018. "Besaran UMP dan UMK DIY2018, MulaiBerlaku 1 Januari”. https:// jogja.tribunnews.com/2018/01/02/inilahbesaran-ump-dan-umk-diy-2018-mulaiberlaku-1-januari, accessed on March 29, 2019.

Utomo, Ariane; Anna Reimondos, Iwu Dwisetyani Utomo, Peter McDonald \& Terence Hull. 2013. "Female Migrants and the Transition to Adulthood in Greater Jakarta". The Annals of the American Academy of Political and Social Science Vol. 648. American Academy of Political and Social Sciences.

Werlin, Herbert. 1974. "The Informal Sector: The Implications of the ILO's Study of Kenya". African Studies Review, Vol. 17, No. 1. Cambridge University Press.

Widarjono, Agus. 2013. Ekonometrika Pengantar dan Aplikasinya. Yogyakarta: UPP STIM YKPN.

Widodo, Ahmadi. 2002. Faktor-Faktor Yang Memengaruhi Pemilihan Lokasi Usaha PKL, Studi Kasus Kota Semarang. Unpublished Thesis. Program Pascasarjana, Magister Teknik Pembangunan Kota, Universitas Diponegoro, Semarang. 